\title{
Standardization of Planting Materials in Tuberose (Polianthes tuberosa L.) cv. Arka Prajwal
}

\author{
A. Sankari ${ }^{1}$, P. Loganayaki ${ }^{2}$, K. Kayalvizhi ${ }^{2}$, M. Kavitha ${ }^{2}$ and R. Jerlin ${ }^{2}$ \\ ${ }^{1}$ Department of Vegetable Science, Tamil Nadu Agricultural University, Coimbatore, India \\ ${ }^{2}$ Tamil Nadu Agricultural University, Coimbatore India \\ *Corresponding author
}

\section{Keywords}

Tuberose, bulbs, gibberellic acid, sprouting percentage, growth.

Article Info Accepted: 15 December 2019 Available Online: 20January 2020

\section{A B S T R A C T}

Tuberose is one of the important commercially cultivated loose flower crops known for its fragrant white flowers. The area under the cultivation of tuberose is being increasing among the farmers. But, the availability of quality planting materials and high cost for the healthy bulbs remains a great hindrance for tuberose cultivation. Hence, an investigation was carried out at the Department of Floriculture and Landscaping, Horticultural College and Research Institute, Tamil Nadu Agricultural University at Coimbatore during 20182019 on tuberose with the objective of standardizing the planting materials for mass multiplication in tuberose. The treatment details are mother bulbs are divided into different parts and also treated with $\mathrm{GA}_{3}$ at different concentrations. Various morphological observations were recorded during nursery stages viz., Days taken for sprouting, plant height, number of leaves per bulb, days taken for $70 \%$ sprouting (days), number of sprouts per bulb, leaf length $(\mathrm{cm})$, leaf width $(\mathrm{cm})$, root length $(\mathrm{cm})$, number of roots per bulb, sprouting percentage $(\%)$. This study revealed that, at nursery stage, bulbs cut into two halves $\left(\mathrm{P}_{2}\right)$ showed minimum number of days taken for sprouting (4 days).Days taken for $70 \%$ sprouting recorded minimum days (4days) for bulbs cut into two halves $\left(\mathrm{P}_{2}\right)$. Maximum plant height of $28.35 \mathrm{~cm}$ was observed in bulbs cut into four halves $\left(\mathrm{P}_{4}\right)$ at 60 DAP in nursery. At 60 DAP, maximum number of leaves (5.70) was recorded in whole bulbs $\left(\mathrm{P}_{1}\right)$.Maximum leaf length of $26.55 \mathrm{~cm}$ was observed in bulbs cut into four halves $\left(\mathrm{P}_{3}\right)$ in nursery at 60 DAP. Bulbs cut into two halves $\left(\mathrm{P}_{2}\right)$ was showed highest number of sprouts (90) at 60 DAP. Bulbs cut into two halves $\left(\mathrm{P}_{2}\right)$ was reported highest plant vigour (3885) at 60 DAP. Maximum relative growth rate $(0.016 \mathrm{mg} / \mathrm{g} / \mathrm{day})$ was recorded in bulbs cut into two halves $\left(\mathrm{P}_{2}\right)$ at nursery stage.

\section{Introduction}

Floriculture includes cultivation of flowering and ornamental plants for direct sale or for use as raw materials in cosmetic and perfume industry and in the pharmaceutical sector. It also includes production of planting materials through seeds, cuttings, budding and grafting. The quality planting materials influences the growth and yield of tuberose plant. Tuberose (Polianthes tuberosa L.) is a bulbous perennial plant belonging to the family Asparagaceae with chromosome number $2 \mathrm{n}=$ 60. (De L.E., 2011). It is one of the important 
commercially cultivated loose flower crops known for its fragrant white flowers. Tuberose is cultivated on large scale in France, Italy, South Africa, North Carolina in USA and in many tropical and plant. Tuberose is mainly used for garland making, hair adornment and oil extraction with recovery percentage of about $0.08-0.11 \%$ and double types are used as cut flower. It is propagated through bulbs and bulblets and seeds but the commercially used propagating material is bulbs.

In India, tuberose is mainly cultivated in Mysore, Tumkur, Belgaum and Devanhalli taluk (Karnataka), Coimbatore, Madurai, Dharmapuri and Kanyakumari districts (Tamil Nadu), Midnapore, Kolaghat, Panskura, Ranaghat and Krishna Nagar (West Bengal), East Godavari, Guntur, Chitoor and Krishna districts (Andhra Pradesh), Guwahati and Jorhat (Assam), Navsari and Valsad (Gujarat), Pune, Thane, Sangli (Maharashtra), Uttar Pradesh, Punjab and Haryana. In India tuberose is commercially cultivated in over 3000 hectare. Since the area under the cultivation of tuberose is being increasing in Tamil Nadu among the farmers. But, the availability of quality planting materials and high cost for the healthy bulbs remains a great hindrance for tuberose cultivation. Hence, the present study has been taken up with the following objectives of standardizing the planting materials for mass multiplication of tuberose.

\section{Materials and Methods}

The experiment was conducted at the Botanic Garden, Department of Floriculture and Landscaping, Horticultural College and Research Institute, Tamil Nadu Agricultural University, Coimbatore which is located in $11^{\circ} .02$ " North latitude and $76^{0} .57^{\prime \prime}$ East longitude and in altitude of 426.72 meters above MSL. The experiment was conducted in Completely Randomised Block Design with 12 treatments replicated twice.

\section{Treatment details}

\begin{tabular}{|l|l|l|}
\hline $\mathbf{T}_{\mathbf{1}}$ & - & Mother bulbs (Control) \\
\hline $\mathbf{T}_{\mathbf{2}}$ & - & Mother Bulbs cut into 2 halves \\
\hline $\mathbf{T}_{\mathbf{3}}$ & - & Mother Bulbs cut into 4 halves \\
\hline $\mathbf{T}_{\mathbf{4}}$ & - & Bulblets (Medium size bulbs) \\
\hline $\mathbf{T}_{\mathbf{5}}$ & - & Mother bulbs scooped bulbs with single bud \\
\hline $\mathbf{T}_{\mathbf{6}}$ & - & Mother bulbs scooped bulbs with two buds \\
\hline $\mathbf{T}_{\mathbf{7}}$ & - & Mother bulbs and GA $@ 150$ ppm soaked for 24 hours \\
\hline $\mathbf{T}_{\mathbf{8}}$ & - & Mother bulb cut into 2 halves and GA $@ 150$ ppm soaked for 24 hours \\
\hline $\mathbf{T}_{\mathbf{9}}$ & - & Mother bulbs cut into 4 halves with GA $@ 150$ ppm soaked for 24 hours \\
\hline $\mathbf{T}_{10}$ & - & Bulblets (Medium size) with GA $@ 150$ ppm soaked for 24 hours \\
\hline $\mathbf{T}_{11}$ & - & Mother bulbs scooped bulbs with single buds GA 3 @ 150ppm soaked for 24 hours \\
\hline $\mathbf{T}_{12}$ & - & Scooped bulbs with two buds GA $@ 150$ ppm soaked for 24 hours \\
\hline
\end{tabular}


The cultivar used in the study is Arka Prajwal. The bulbs are two years old and it stored upto one month for better sprouting. The treatments details are furnished below: One healthy bulb was planted in one cell in protray. Before planting the bulbs were soaked in gibberellic acid at $150 \mathrm{ppm}$ for 24 hours. The growth regulators treated bulbs were dipped in bavistin $1 \mathrm{~g} / \mathrm{l}$ for half an hour to avoid the fungal diseases. Bulbs were planted at the individual cell in protray. Irrigation was done at alternate days at nursery stage.

At 30 days after planting, the medium was drenched with Bavistin @1g/l of water for protection from fungus diseases. The observations were recorded in nursery stage on 30 DAP and 60 DAP viz., days taken for sprouting (days), days taken for $70 \%$ sprouting (days), sprouting percentage (\%), number of sprouts per bulb (Nos.), plant height $(\mathrm{cm})$, number of leaves per bulb (Nos.), leaf length $(\mathrm{cm})$, leaf width $(\mathrm{cm})$, root length $(\mathrm{cm})$ and number of roots per bulb(Nos.). were recorded from five randomly selected plants of each replication using standard procedure. The data generated during the course of study was subjected to statistical analysis as prescribed by Panse and Sukhatme (2000).

\section{Results and Discussion}

The effect of bulb sizes and growth regulators in nursery stage. Growth parameters viz., days taken for sprouting, sprouting percentage, plant height $(\mathrm{cm})$, number of leaves per clump, leaf length $(\mathrm{cm})$, leaf width $(\mathrm{cm})$, number of roots per clump, root length $(\mathrm{cm})$, plant vigour, root/shoot ratio were recorded and the results are presented in the Table 1,2 and 3.

From table 2, the maximum height of plant in $\mathrm{P}_{3}$ (bulbs cut into four halves) recorded 13.20 $\mathrm{cm}$ and $26.55 \mathrm{~cm}$ at 30 days and 60 days respectively followed by $\mathrm{P}_{2}$ (bulbs cut into two halves) $(12.70 \mathrm{~cm}$ and $25.85 \mathrm{~cm}$ at 30 days and 60 days respectively).

The minimum height of plant in $\mathrm{P}_{12}$ (Scooped bulbs with two buds $\mathrm{GA}_{3} @ 150$ ppm soaked for 24 hours) recorded $5.70 \mathrm{~cm}$ and $14.60 \mathrm{~cm}$ at 30 days and 60 days respectively). The improved plant height may be due to some amount of stored food materials present in cut bulbs helped in early and rapid growth of the sprouts as reported by Mahesan et al., (2015).

The number of leaves per clump was highly significant among the treatments in this nursery. The data on number of leaves per clump were observed presented in table 2 . The more number of leaves in $\mathrm{P}_{1}$ (Whole bulbs) are observed 4.50 and 5.70 followed by $\mathrm{P}_{2}$ (4.40 and 5.35). The less number of leaves in $\mathrm{P}_{12}$ (Scooped bulbs with two buds $\mathrm{GA}_{3}$ @ 150 ppm soaked for 24 hours) are recorded 1.80 and 2.45.Significant difference observed in this treatment after nursery on leaf length. The data were given in table 2 .

The maximum leaf length in $\mathrm{P}_{3}$ (bulbs cut into four halves) recorded $13.20 \mathrm{~cm}$ and $26.55 \mathrm{~cm}$ at 30 days and 60 days respectively followed by $\mathrm{P}_{2}$ (bulbs cut into two halves) $(12.70 \mathrm{~cm}$ and $25.85 \mathrm{~cm}$ at 30 days and 60 days respectively). The minimum leaf length in $\mathrm{P}_{12}$ (Scooped bulbs with two buds GA3@150 ppm soaked for 24 hours) recorded $5.70 \mathrm{~cm}$ and $14.60 \mathrm{~cm}$ at 30 days and 60 days respectively).

The width of leaf observed in after nursery stage for different types of planting materials presented in table 2.There was significant variation on leaf width. $\mathrm{P}_{3}$ (bulbs cut into four halves) were obtained highest width of leaf $(1.80 \mathrm{~cm})$ followed by $\mathrm{P}_{4}$ (bulblets) $(1.70 \mathrm{~cm})$ after transplanting the main field. $\mathrm{P}_{12}$ (Scooped bulbs with two buds GA 3 @150 ppm soaked for 24 hours) were obtained $(0.95 \mathrm{~cm})$ (Table 2). $\mathrm{P}_{2}$ (bulbs cut into two 
halves) were obtained highest width of leaf $(1.70 \mathrm{~cm})$ followed by $\mathrm{P}_{3}$ (bulbs cut into half halves) $(1.50 \mathrm{~cm})$ after transplanting the main field. $\mathrm{P}_{12}$ (Scooped bulbs with two buds $\mathrm{GA}_{3}$ @ 150 ppm soaked for 24 hours) were obtained $(1 \mathrm{~cm})$. (Table 2).

The increased bulb size promotes emergence of more leaves and the highest leaf length and leaf width in tuberose are accordance with the results of Rao et al., (1992) and Mahanata et al., (1998) also have stated that the bulb size is directly proportional to number of leaves in tuberose. The number of roots per clump was highly significant among the treatments in this nursery.

The data on number of roots per clump were presented in table 3 . The more number of roots per clump recorded $\mathrm{P}_{1}$ (whole bulbs) (14.90 and 21.954 .90 at 30 days and 60 days respectively) followed by $\mathrm{P}_{2}$ (bulbs cut into two halves) and $\mathrm{P}_{7}$ (Whole bulbs and $\mathrm{GA}_{3}$ @ $150 \mathrm{ppm}$ soaked for 24 hours) recorded 10.60 at 30 days and 60 days respectively. The less number of roots in $\mathrm{P}_{11}$ (Scooped bulbs with single buds $\mathrm{GA}_{3} @ 150$ ppm soaked for 24 hours) recorded 2.80 and 4.90 at 30 days and 60 days respectively.

The length of root observed after planting in the nursery for different types of planting materials presented in table 3.There was significant variation on root length. The mean value of length of root ranged from $2.20 \mathrm{~cm}$ to $8.35 \mathrm{~cm}$ at $30 \mathrm{DAP}$. From table 3 , the $\mathrm{P}_{4}$ (bulblets) recorded maximum root length $8.35 \mathrm{~cm}$ followed by $\mathrm{P}_{2}$ (bulbs cut into two halves) showed in $7.80 \mathrm{~cm} . \mathrm{P}_{11}$ (Scooped bulbs with single buds $\mathrm{GA}_{3} @ 150$ ppm soaked for 24 hours) recorded the minimum root length $(2.20 \mathrm{~cm})$. The mean value of length of root ranged from $4.15 \mathrm{~cm}$ to 12.30 $\mathrm{cm}$ at $60 \mathrm{DAP}$.

From table 3 , the $\mathrm{P}_{2}$ (bulbs cut into two halves) recorded maximum root length (12.30 $\mathrm{cm}$ ) followed by $\mathrm{P}_{4}$ (bulblets) observed in $11.05 \mathrm{~cm} . \mathrm{P}_{12}$ (Scooped bulbs with two buds $\mathrm{GA}_{3} @ 150$ ppm soaked for 24 hours) showed the minimum root length $(4.15 \mathrm{~cm})$.Highly significant influenced among the different planting materials on number of sprouts.

The data on number of sprouts are presented in table 3. $\mathrm{P}_{2}$ (bulb cut into two halves) recorded highest number of sprouts $(90.00$ both 30days and 60 days respectively) followed by $\mathrm{P}_{3}$ (bulb cut into two halves) showed in (both 87.00 30days and 60 days respectively).Lowest number of sprouts was registered in the $\mathrm{P}_{11}$ (Scooped bulbs with single buds $\mathrm{GA}_{3} @ 150$ ppm soaked for 24 hours) for (31 and 54.50) compared to control. Roland Ennos et al., (1990) reported that root length supports for better anchorage of sprouted bulbs in the soil.

Significant difference observed due to bulb size in nursery stage on plant vigour. $\mathrm{P}_{2}$ (bulb cut into two halves) recorded highest vigour of plant (2220 and 3885 at 30days and 60 days respectively) followed by $\mathrm{P}_{3}$ (bulb cut into two halves) for (2080.35 and 3785 at 30 days and 60 days respectively).

Lowest vigour of plants (319.45 and 1413.70 at 30days and 60 days respectively) was registered in the $\mathrm{P}_{11}$ (Scooped bulbs with single buds $\mathrm{GA}_{3} @ 150$ ppm soaked for 24 hours) compared to control. (Table 3). Among all the treatments, $\mathrm{P}_{2}$ (bulb cut into two halves) recorded significantly the maximum plant root/shoot dry weight ratio (1.16 and 1.70 at 30 days and 60 days respectively) followed by $\mathrm{P}_{3}$ (bulb cut into four halves) recorded (0.48 and 0.54). The minimum plant shoot/root dry weight ratio (0.02) obtained $\mathrm{P}_{6}$ (Scooped bulbs with two buds), $\mathrm{P}_{1}$ (Whole bulbs) and $\mathrm{P}_{7}$ (Whole bulbs and $\mathrm{GA}_{3} @ 150$ ppm soaked for 24 hours) in $30^{\text {th }}$ day and $60^{\text {th }}$ day respectively compared to control.(Table 3) 
Table.1 Effect of different bulbsizes and bulblets on days taken for sprouting (days) and days taken for $70 \%$ sprouting (days)

\begin{tabular}{|c|c|c|}
\hline Treatments & Days taken for sprouting(days) & Days taken for $\mathbf{7 0 \%}$ \\
\hline $\mathbf{T}_{\mathbf{1}}$ & 13.00 & 61.00 \\
\hline $\mathbf{T}_{\mathbf{2}}$ & 4.50 & 9.00 \\
\hline $\mathbf{T}_{\mathbf{3}}$ & 5.50 & 13.00 \\
\hline $\mathbf{T}_{\mathbf{4}}$ & 10.00 & 20.50 \\
\hline $\mathbf{T}_{\mathbf{5}}$ & 11.00 & 27.00 \\
\hline $\mathbf{T}_{\mathbf{6}}$ & 10.50 & 36.50 \\
\hline $\mathbf{T}_{\mathbf{7}}$ & 14.00 & 59.00 \\
\hline $\mathbf{T}_{\mathbf{8}}$ & 6.00 & 25.00 \\
\hline $\mathbf{T}_{\mathbf{9}}$ & 6.50 & 24.00 \\
\hline $\mathbf{T}_{\mathbf{1 0}}$ & 7.00 & 21.50 \\
\hline $\mathbf{T}_{\mathbf{1 1}}$ & 16.00 & 60.00 \\
\hline $\mathbf{T}_{\mathbf{1 2}}$ & 12.00 & 45.00 \\
\hline Mean & 9.67 & 33.46 \\
\hline $\mathbf{S E}(\mathbf{d})$ & 1.84 & 6.57 \\
\hline $\mathbf{C D}(\mathbf{P}=\mathbf{0 . 0 5 \% )}$ & 4.00 & 14.30 \\
\hline $\mathbf{M}$ & & \\
\hline & & \\
\hline
\end{tabular}

$\mathrm{T}_{1} \quad$ - Mother bulbs (Control)

$\mathrm{T}_{2} \quad$ - Mother bulbs cut into 2 halves

$\mathrm{T}_{3} \quad$ - Motherbulbs cut into 4 halves

$\mathrm{T}_{4} \quad$ - Bulblets (Medium size)

$\mathrm{T}_{5} \quad$ - Motherbulbs scooped with single bud

$\mathrm{T}_{6} \quad$ - Motherbulbs Scooped with two buds

$\mathrm{T}_{7} \quad$ - Motherbulbs and $\mathrm{GA}_{3} @ 150$ ppm soaked for 24 hours

$\mathrm{T}_{8} \quad$ - Motherbulbs cut into 2 halves and $\mathrm{GA}_{3} @ 150$ ppm soaked for 24 hours

$\mathrm{T}_{9} \quad$ - Motherbulbs cut into 4 halves with $\mathrm{GA}_{3} @ 150$ ppm soaked for 24 hours

$\mathrm{T}_{10} \quad$ - Bulblets with $\mathrm{GA}_{3} @ 150$ ppm soaked for 24 hours

$\mathrm{T}_{11}$ - Motherbulbs scooped with single buds GA $\mathrm{A}_{3} @ 150$ ppm soaked for 24 hours

$\mathrm{T}_{12} \quad$ - Motherbulbs Scooped with two buds GA $\mathrm{A}_{3} @ 150$ ppm soaked for 24 hours 
Table.2 Effect of different bulbsizes and bulblets on plant height $(\mathrm{cm})$ and number of leaves, leaf length $(\mathrm{cm})$, leaf breadth $(\mathrm{cm})$, number of roots per clump and root length $(\mathrm{cm})$

\begin{tabular}{|c|c|c|c|c|c|c|c|c|c|c|c|c|}
\hline \multirow{2}{*}{$\begin{array}{l}\text { Characters } \\
\text { Treatments }\end{array}$} & \multicolumn{2}{|c|}{$\begin{array}{l}\text { Plant height } \\
\text { (cm) }\end{array}$} & \multicolumn{2}{|c|}{$\begin{array}{c}\text { Number of } \\
\text { leaves }\end{array}$} & \multicolumn{2}{|c|}{$\begin{array}{c}\text { Leaf } \\
\text { length }(\mathrm{cm})\end{array}$} & \multicolumn{2}{|c|}{$\begin{array}{c}\text { Leaf } \\
\text { width }(\mathrm{cm})\end{array}$} & \multicolumn{2}{|c|}{$\begin{array}{l}\text { Number of } \\
\text { roots per } \\
\text { clump }\end{array}$} & \multicolumn{2}{|c|}{$\begin{array}{c}\text { Root } \\
\text { length }(\mathrm{cm})\end{array}$} \\
\hline & $\begin{array}{l}30^{\text {th }} \\
\text { day }\end{array}$ & $\begin{array}{l}60^{\text {th }} \\
\text { day }\end{array}$ & $\begin{array}{l}30^{\text {th }} \\
\text { day }\end{array}$ & $\begin{array}{l}60^{\text {th }} \\
\text { day }\end{array}$ & $\begin{array}{l}30^{\text {th }} \\
\text { day }\end{array}$ & $\begin{array}{l}60^{\text {th }} \\
\text { day }\end{array}$ & $\begin{array}{l}30^{\text {th }} \\
\text { day }\end{array}$ & $\begin{array}{l}60^{\text {th }} \\
\text { day }\end{array}$ & $\begin{array}{l}30^{\text {th }} \\
\text { day }\end{array}$ & $\begin{array}{l}60^{\text {th }} \\
\text { day }\end{array}$ & $\begin{array}{l}30^{\text {th }} \\
\text { day }\end{array}$ & $\begin{array}{l}60^{\text {th }} \\
\text { day }\end{array}$ \\
\hline $\mathbf{T}_{1}$ & 12.30 & 25.00 & 4.50 & 5.70 & 12.90 & 18.60 & 1.30 & 1.30 & 14.90 & 21.95 & 4.95 & 9.10 \\
\hline$T_{2}$ & 14.40 & 26.55 & 4.40 & 5.35 & 12.70 & 25.85 & 1.50 & 1.70 & 10.60 & 17.00 & 7.80 & 12.30 \\
\hline $\mathbf{T}_{\mathbf{3}}$ & 19.00 & 28.35 & 4.20 & 4.00 & 13.20 & 26.55 & 1.80 & 1.50 & 9.80 & 14.25 & 6.65 & 9.45 \\
\hline $\mathbf{T}_{4}$ & 14.60 & 26.15 & 3.20 & 3.95 & 4.65 & 24.85 & 1.70 & 1.35 & 9.30 & 16.75 & 8.35 & 11.05 \\
\hline $\mathbf{T}_{5}$ & 8.90 & 21.85 & 2.40 & 2.95 & 9.15 & 21.95 & 1.00 & 0.95 & 3.80 & 7.80 & 5.25 & 8.10 \\
\hline $\mathbf{T}_{6}$ & 9.10 & 23.25 & 2.00 & 3.25 & 9.00 & 22.40 & 1.05 & 1.10 & 3.20 & 5.45 & 3.85 & 5.20 \\
\hline $\mathbf{T}_{7}$ & 10.10 & 24.40 & 3.05 & 4.75 & 11.45 & 24.70 & 1.35 & 1.20 & 8.05 & 18.05 & 3.30 & 5.55 \\
\hline$T_{8}$ & 11.60 & 22.65 & 3.25 & 5.45 & 8.60 & 21.70 & 1.20 & 1.45 & 8.15 & 13.20 & 4.40 & 8.45 \\
\hline$T_{9}$ & 9.30 & 18.65 & 2.05 & 2.00 & 6.95 & 12.40 & 1.60 & 1.60 & 3.35 & 6.15 & 3.55 & 6.85 \\
\hline$T_{10}$ & 14.80 & 25.65 & 1.90 & 2.35 & 7.80 & 24.55 & 1.45 & 1.40 & 8.65 & 14.80 & 3.45 & 6.90 \\
\hline$T_{11}$ & 7.00 & 19.10 & 2.50 & 3.00 & 6.40 & 18.15 & 1.40 & 1.15 & 2.80 & 4.90 & 2.20 & 4.20 \\
\hline$T_{12}$ & 5.80 & 14.10 & 1.80 & 2.45 & 5.70 & 14.60 & 0.95 & 1.00 & 2.90 & 5.00 & 2.35 & 4.15 \\
\hline Mean & 11.39 & 22.98 & 2.94 & 3.77 & 9.90 & 21.36 & 1.36 & 1.31 & 7.13 & 12.11 & 4.68 & 7.61 \\
\hline SE(d) & 0.27 & 0.67 & 0.10 & 0.11 & 0.20 & 2.14 & 0.04 & 0.07 & 0.18 & 0.34 & 0.10 & 0.02 \\
\hline $\begin{array}{c}\text { CD } \\
(P=\mathbf{P . 0 5 \%})\end{array}$ & 0.58 & 1.44 & 0.22 & 0.24 & 0.44 & 4.67 & 0.09 & 0.14 & 0.39 & 0.73 & 0.21 & 0.14 \\
\hline
\end{tabular}


Table.3 Effect of different bulb sizes and bulblets on number of sprouts, plant vigour, plant shoot and dry weight ratio and Relative growth rate

\begin{tabular}{|c|c|c|c|c|c|c|c|}
\hline \multirow{2}{*}{$\begin{array}{l}\text { Characters } \\
\text { Treatments }\end{array}$} & \multicolumn{2}{|c|}{ Number of sprouts } & \multicolumn{2}{|c|}{ Plant vigour } & \multicolumn{2}{|c|}{$\begin{array}{c}\text { plant shoot/root dry } \\
\text { weight ratio }\end{array}$} & \multirow{2}{*}{$\begin{array}{c}\text { Relative } \\
\text { growth } \\
\text { rate }\end{array}$} \\
\hline & $30^{\text {th }}$ day & $60^{\text {th }}$ day & $30^{\text {th }}$ day & $60^{\text {th }}$ day & $30^{\text {th }}$ day & $60^{\text {th }}$ day & \\
\hline $\mathbf{T}_{1}$ & 44.50 & 58.50 & 851.90 & 2215.30 & 0.02 & 0.02 & 0.009 \\
\hline $\mathbf{T}_{2}$ & 90.00 & 90.00 & 2220.00 & 3885.00 & 1.16 & 1.70 & 0.016 \\
\hline $\mathbf{T}_{3}$ & 87.00 & 88.85 & 2080.35 & 3785.00 & 0.48 & 0.54 & 0.011 \\
\hline $\mathbf{T}_{4}$ & 81.50 & 88.95 & 2059.90 & 3760.00 & 0.10 & 0.13 & 0.012 \\
\hline $\mathbf{T}_{5}$ & 62.00 & 71.50 & 976.15 & 2374.10 & 0.04 & 0.05 & 0.005 \\
\hline $\mathbf{T}_{6}$ & 50.50 & 65.50 & 655.85 & 2069.90 & 0.02 & 0.33 & 0.004 \\
\hline $\mathbf{T}_{7}$ & 45.00 & 66.50 & 668.15 & 2211.20 & 0.02 & 0.04 & 0.006 \\
\hline $\mathbf{T}_{8}$ & 73.50 & 85.50 & 1302.40 & 2953.70 & 0.05 & 0.06 & 0.002 \\
\hline $\mathbf{T}_{9}$ & 69.50 & 84.50 & 988.78 & 2398.10 & 0.06 & 0.07 & 0.004 \\
\hline $\mathbf{T}_{10}$ & 72.50 & 85.00 & 1475.75 & 3072.95 & 0.03 & 0.04 & 0.006 \\
\hline $\mathbf{T}_{11}$ & 31.00 & 54.50 & 319.45 & 1413.70 & 0.04 & 0.07 & 0.005 \\
\hline $\mathbf{T}_{12}$ & 54.00 & 71.00 & 475.80 & 1443.65 & 0.05 & 0.06 & 0.010 \\
\hline Mean & 63.42 & 70.03 & 1206.21 & 2631.47 & 0.17 & 0.23 & 0.011 \\
\hline SE(d) & 7.89 & 6.33 & 123.44 & 007.06 & 0.06 & 0.08 & 0.001 \\
\hline $\begin{array}{c}\text { CD } \\
(P=0.05 \%)\end{array}$ & 17.90 & 13.80 & 268.95 & 015.39 & 0.14 & 0.17 & 0.002 \\
\hline
\end{tabular}

When comparing the mean effects of bulb size significantly difference, freshly $\mathrm{P}_{2}$ (bulb cut into two halves) registered the maximum $\left(100 \%\right.$ both $30^{\text {th }}$ day and $60^{\text {th }}$ day respectively) sprouting percentage(table 5) followed by $\mathrm{P}_{3}$ (bulb cut into four halves) (99.95\% and 96.70 at $30^{\text {th }}$ day and $60^{\text {th }}$ day respectively). Scooped bulbs with single buds $\mathrm{GA}_{3} @ 150$ ppm soaked for 24 hours $\left(\mathrm{P}_{11}\right)$ recorded minimum (60.55 and 36.70 at $30^{\text {th }}$ day and $60^{\text {th }}$ day respectively)sprouting percentage. (Table 5)

Significant result found the effect of treatments on day of sprouting on earlier $\left(\mathrm{P}_{2}\right.$, bulb cut into two halves) took around 4.5 days followed $\mathrm{P}_{3}$ (bulb cut into four halves) took around 5.50 days. The delay of sprouting of days $\left(\mathrm{P}_{11}\right.$, Scooped bulbs with single buds
$\mathrm{GA}_{3} @ 150$ ppm soaked for 24 hours) took around 16 days. This may be attributed that to the fact that dormancy breaking of apical bud takes place earlier than that of auxiliary buds present on cut pieces. (Mahesan et al., (2015).

Significant result found the effect of treatments on day of sprouting on earlier $\left(\mathrm{P}_{2}\right.$, bulb cut into two halves) took around 9 days followed $\mathrm{P}_{3}$ (bulb cut into four halves) took around 13 days. The delay of sprouting of days $\left(\mathrm{P}_{11}\right.$, Scooped bulbs with single buds $\mathrm{GA}_{3} @ 150$ ppm soaked for 24 hours) took around 60 days. The improved sprouting percentage may be due to bulbs with two halves that contained higher amount food reserves at the base on bulbs as reported by Iftikhar Ahmad et al., (2009). 
Significant differences were observed among bulb types on relative growth rate. Bulbs cut into two halves $\left(\mathrm{P}_{2}\right)$ recorded more relative growth rate $(0.016 \mathrm{mg} / \mathrm{g} /$ day $)$ followed by bulblets $\left(\mathrm{P}_{4}\right)$.

Bulbs cut into 2 halves and $\mathrm{GA}_{3} @ 150$ ppm soaked for 24 hours $\left(\mathrm{P}_{8}\right)$ registered the less number of relative growth rate $(0.002 \mathrm{mg} / \mathrm{g} /$ day).(table 3$)$. Biomass allocation to the leaves and ratio between leaf area and leaf weight were positively correlated with Plant Growth Rate. The results were in a concurrence to the findings of Hendrick porter, (1989).

In this research different planting materials were used to find out the best quality materials to increase the growth and yield of tuberose plants. Finally bulbs cut into two halves, bulbs cut into four halves and bulbllets were standardized as the best planting materials at the nursery stage.

At nursery stage, bulbs cut into two halves $\left(\mathrm{P}_{2}\right)$ showed minimum number of days taken for sprouting (4 days).Days taken for $70 \%$ sprouting recorded minimum days (4days) for bulbs cut into two halves $\left(\mathrm{P}_{2}\right)$.Maximum plant height of $28.35 \mathrm{~cm}$ was observed in bulbs cut into four halves $\left(\mathrm{P}_{4}\right)$ at 60 DAPin nursery.

At 60 DAP, maximum number of leaves (5.70) was recorded in whole bulbs $\left(\mathrm{P}_{1}\right)$.Maximum leaf length of $26.55 \mathrm{~cm}$ was observed in bulbs cut into four halves $\left(\mathrm{P}_{3}\right)$ in nursery at 60 DAP. Bulbs cut into two halves $\left(\mathrm{P}_{2}\right)$ was showed highest number of sprouts(90) at 60 DAP.

Bulbs cut into two halves $\left(\mathrm{P}_{2}\right)$ was reported highest plant vigour (3885) at 60 DAP. Maximum relative growth rate $(0.016$ $\mathrm{mg} / \mathrm{g} /$ day)was recorded in bulbs cut into two halves $\left(\mathrm{P}_{2}\right)$ at nursery stage.

\section{References}

Hendrick Poorter. Interspecific variation in relative growth rate: on ecological causes and physiological consequences. SPB Academic Publishing, 1989, 45-68.

Iftikhar Ahmad, Tanveer Ahmad, Muhammad Asif, Muhammad Saleem, Ahsan Akram. Effect of bulbsize on growth, flowering and bulbils production of tuberose. Sarhad. Journal of Agriculture. 2009; 25:3.

Mahanta P, Paswan L. Effect of bulb size and spacing on growth, flowering and bulb production of tuberose (Polianthes tuberosa L.) cv. Hussain et al., Single. Horticultural Science. 1999; 8(1):75-83. 12.

Mahasen M, Ona AF, Taufique T, Mehraj H, Jamal Uddin AFM. Suitability of cut corm as planting materials on flowering and corm-cormels production of gladiolus cultivars. Journal of Bioscience and Agriculture Research. 2015; 4(1):10-19. 13

Panse VG, Sukhatme PV. Statistical methods for agricultural workers. Publication and Information Division of ICAR, New Delhi, 2000.

\section{How to cite this article:}

Sankari. A, P. Loganayaki, K. Kayalvizhi' M. Kavitha and Jerlin. R. 2020. Standardization of Planting Materials in Tuberose (Polianthes tuberosa L.) cv. Arka Prajwal. Int.J.Curr.Microbiol.App.Sci. 9(01): 2046-2053. doi: https://doi.org/10.20546/ijcmas.2020.901.232 